\title{
Study of reticuloendothelial phagocytic capacity in patients with cholestasis
}

\author{
GEORGE DRIVAS, OLIVER JAMES, NIGEL WARDLE
}

British Medical fournal, 1976, 1, 1568-1569

\section{Summary}

The phagocytic capacity of the reticuloendothelial system was studied by the clearance from the plasma of microaggregated iodinated human serum albumin. About half of the patients with cholestasis showed impaired Kupffer-cell phagocytosis. The finding may be relevant to the occurrence of surgical complications in patients with obstructive jaundice.

\section{Introduction}

The Kupffer cells play an important part in removing any micro-organisms in the portal blood, in inactivating endotoxin,,$^{12}$ and in clearing macromolecules ${ }^{3}$ or immune complexes. ${ }^{4}$ They also play a part in the removal of fibrin and fibrin complexes of high molecular weight in states associated with intravascular coagulation. Indeed in both endotoxinaemia and other states of disseminated intravascular coagulation blockade of the reticuloendothelial system (RES) may result in renal cortical necrosis. ${ }^{5}$ Since endotoxinaemia is related to the onset of renal failure in patients with obstructive jaundice ${ }^{7}$ or hepatic failure ${ }^{8}$ current interest centres on the functional activity of the Kupffer cells of the liver in the several types of liver disease. ${ }^{910}$

The RES phagocytic capacity, particularly that of the Kupffer cells, can be measured in man by the clearance of microaggregated iodinated human serum albumin. ${ }^{11}{ }^{12}$ We report here the results of studies on patients with obstructive jaundice and other types of liver disease.

Wellcome Research Laboratories, Department of Medicine, Royal Victoria Infirmary, Newcastle upon Tyne NE1 4LP GEORGE DRIVAS, MD, research associate

OLIVER JAMES, MRCP, reader in medicine (geriatrics)

NIGEL WARDLE, MD, MRCP, regional physician

\section{Methods}

Aggregated iodinated human serum albumin was prepared by the method of Ilio and Wagner ${ }^{112}$ and given intravenously with the patient's informed permission at a dose of $5 \mathrm{mg} / \mathrm{kg}$ for the simple RES clearance test. For the serial RES saturation test the microaggregated albumin was given first it a dose of $2.5 \mathrm{mg} / \mathrm{kg}$ followed by collection of blood samples for 20 minutes; then after a rest period of 10 minutes a dose of $5 \mathrm{mg} / \mathrm{kg}$ was given, followed again by blood sampling for 20 minutes; and, finally, after another rest period of 20 minutes 10 $\mathrm{mg} / \mathrm{kg}$ was given. For each test isotope counts were plotted semilogarithmically with time, and the half life of the straight line slope from 8 to 15 minutes was determined by graphical resolution. Normal clearance values in 15 subjects gave a half time of $14 \cdot 1 \pm 3 \cdot 3$ minutes.

\section{Results}

Twenty patients have so far undergone the simple RES clearance test before operation and, when possible, three days afterwards. They included six patients with obstructive jaundice due to stones, five with obstructive jaundice due to carcinoma of the head of the pancreas without evidence of liver metastases, two with liver metastases from carcinoma of the lung, four with cholestatic hepatitis, and three recovering from acute cholecystitis. Their results are presented in table I together with a synopsis of their liver function test results. Among the patients with obstructive jaundice due to stone or cancer

TABLE II-Results (half life in minutes) of RES saturation test

\begin{tabular}{|c|c|c|c|c|}
\hline $\begin{array}{l}\text { Case } \\
\text { No }\end{array}$ & Condition & $2.5 \mathrm{mg} / \mathrm{kg}$ & $5.0 \mathrm{mg} / \mathrm{kg}$ & $10 \mathrm{mg} / \mathrm{kg}$ \\
\hline $\begin{array}{l}21 \\
22 \\
23 \\
24 \\
25 \\
26 \\
27 \\
28 \\
29 \\
30\end{array}$ & $\begin{array}{l}\text { Cirrhosis } \\
\text { ", } \\
\text { Chronic hepatitis } \\
\text { Obstructive jaundice } \\
\text { ", ", } \\
\text { Cholecystitis }\end{array}$ & $\begin{array}{r}9 \cdot 0 \\
8 \cdot 6 \\
11 \cdot 5 \\
9 \cdot 0 \\
10 \cdot 6 \\
12 \cdot 0 \\
9 \cdot 0 \\
10 \cdot 0 \\
5 \cdot 0 \\
4 \cdot 8\end{array}$ & $\begin{array}{l}12 \cdot 5 \\
22 \cdot 0 \\
26 \cdot 0 \\
16 \cdot 0 \\
17 \cdot 0 \\
25 \cdot 5 \\
12 \cdot 0 \\
18 \cdot 0 \\
10 \cdot 0 \\
19 \cdot 0\end{array}$ & $\begin{array}{l}27 \cdot 5 \\
31 \cdot 5^{*} \\
46 \cdot 0^{*} \\
28 \cdot 0 \\
38 \cdot 0^{*} \\
42 \cdot 0^{*} \\
31 \cdot 0^{*} \\
31 \cdot 0^{*} \\
20 \cdot 0 \\
27 \cdot 0\end{array}$ \\
\hline Mean & & $7 \cdot 7$ & $17 \cdot 8$ & $32 \cdot 2$ \\
\hline \multicolumn{2}{|c|}{12 normal controls } & $6 \cdot 7 \div 2 \cdot 0$ & $13 \cdot 1 \pm 3 \cdot 0$ & $20 \cdot 4 \div 4 \cdot 2$ \\
\hline
\end{tabular}

*Abnormal cases.

TABLE I-Results of simple RES clearance test and liver function values in patients with cholestasis or cholecystitis

\begin{tabular}{|c|c|c|c|c|c|c|}
\hline \multirow{2}{*}{$\begin{array}{c}\text { Case } \\
\text { No }\end{array}$} & \multirow{2}{*}{ Type of obstruction } & \multicolumn{2}{|c|}{ Half life (minutes) } & \multirow{2}{*}{$\underset{\substack{\text { Serum } \\
\text { bilirubin } \\
(\mu \mathrm{mol} / \mathrm{l})}}{\cos }$} & \multirow{2}{*}{$\begin{array}{c}\text { Alkaline } \\
\text { phosphatase } \\
\text { (IU/l) }\end{array}$} & \multirow{2}{*}{$\begin{array}{c}\text { Aspartate } \\
\text { aminotransferase } \\
(\text { IU } / 1)\end{array}$} \\
\hline & & Before operation & After operation & & & \\
\hline $\begin{array}{r}1 \\
2 \\
3 \\
4 \\
5 \\
6 \\
7 \\
8 \\
9 \\
10 \\
11 \\
12 \\
13 \\
14 \\
15 \\
16 \\
17 \\
18 \\
19 \\
20\end{array}$ & $\begin{array}{l}\text { Gall stone } \\
\text { ", ", } \\
\text { ", ", } \\
\text { Cancer of pancreas } \\
\text { ", ", } \\
\text { ", ", } \\
\text { Liver metastases } \\
\text { Cholestatic jaundice } \\
\text { ", ", } \\
\text { Cholecystitis ", } \\
\text { ", }\end{array}$ & 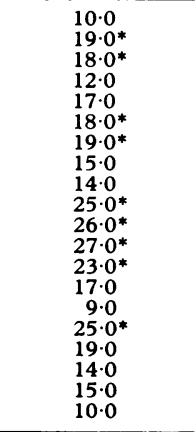 & $\begin{array}{r}10 \cdot 0 \\
16 \cdot 5 \\
12 \cdot 0 \\
6 \cdot 4 \\
12 \cdot 0 \\
11 \cdot 0 \\
15 \cdot 0 \\
11 \cdot 0 \\
12 \cdot 0 \\
16 \cdot 0 \\
8 \cdot 0 \\
25 \cdot 0 \\
\\
\\
\\
8 \cdot 0 \\
11 \cdot 0 \\
8 \cdot 0\end{array}$ & $\begin{array}{r}123 \\
42 \\
34 \\
198 \\
240 \\
93 \\
390 \\
195 \\
240 \\
282 \\
240 \\
103 \\
52 \\
162 \\
400 \\
256 \\
275 \\
52 \\
67 \\
52\end{array}$ & $\begin{array}{r}98 \\
245 \\
378 \\
315 \\
302 \\
245 \\
238 \\
337 \\
280 \\
259 \\
294 \\
140 \\
196 \\
196 \\
126 \\
302 \\
231 \\
140 \\
133 \\
105\end{array}$ & $\begin{aligned} 80 \\
37 \\
47 \\
54 \\
44 \\
33 \\
29 \\
90 \\
42 \\
71 \\
35 \\
22 \\
28 \\
19 \\
16 \\
77 \\
84 \\
32 \\
31 \\
220\end{aligned}$ \\
\hline Normal values & & \multicolumn{2}{|c|}{$14 \cdot 1 \pm 3 \cdot 3$} & $<17$ & $<100$ & $<30$ \\
\hline
\end{tabular}


of the head of pancreas about half had RES clearance values that were definitely abnormal before operation for relief of the obstruction. After operation the values were lower, and this was so even for patients whose previous values lay within the normal range. Hence Kupffercell clearance was increasing postoperatively, and the same phenomenon was seen in the patients with acute cholecystitis, who actually had accelerated RES clearances during their recovery.

Table II shows the results of the serial RES saturation test in 12 control patients (recovering after a coronary thrombosis) and 10 patients with various liver diseases. Half of these patients had abnormal results, as shown by reference to the clearance time for the $10-\mathrm{mg} / \mathrm{kg}$ dose, for which the normal values were under 30 minutes. Among these abnormal patients were four with obstructive jaundice and two with alcoholic cirrhosis.

\section{Discussion}

The results show that at least half of a group of patients with obstructive jaundice will have defective Kupffer-cell clearance of microaggregated albumin. Although poor liver perfusion may play a part, this is not the whole explanation. The serial RES saturation test shows that we are actually assessing the phagocytic capacity of the Kupffer cells. Support for this comes from the many studies of this type that have been performed in animals. ${ }^{13}$ Using a test based on the sample principles, but very different in details, Cooksley et al ${ }^{14}$ found that RES phagocytic capacity was reduced in some patients with alcoholic cirrhosis. At that time the relevance to obstructive jaundice was not well known, although we had shown in rat experiments that in obstructive jaundice a single dose of endotoxin is sufficient to produce a Shwartzman-type acute renal failure. ${ }^{15}$

Interest in the Kupffer cell in obstructive jaundice centres mainly on the relevance of dysfunction to more severe sequelae of endotoxinaemia and disseminated intravascular coagulation, such as acute renal failure and the respiratory distress syndrome. ${ }^{16}$ In the adverse environment created by raised concentrations of bile acids, which are detergents, and of conjugated bilirubin, which is a metabolic poison, ${ }^{7}$ it would not be surprising if the Kupffer cells could not perform their normal detoxifying function..$^{17 / 8}$ Furthermore, the phagocytic capacity of the RES may be depressed during and after abdominal surgery. ${ }^{19}$ The state of RES perfusion and efficacy in the liver is crucial to the outcome of haemorrhagic, traumatic, and bacterial shock. ${ }^{20}$ So far we have not been able to study any patient under more critical circumstances, but our results show that the subject of RES phagocytic capacity is of developing interest.

The adverse complications of obstructive jaundice probably arise when the body is "caught unaware" by the sudden onset of bacteraemia or endotoxinaemia. The first effect of endotoxin is to impair the function of the Kupffer cells, but thereafter there is Kupffer-cell hyperplasia and endotoxin tolerance. The increased RES activity that is symptomatic of this latter phase may be seen to develop in patients with cholecystitis. Rather than reflecting a change in liver blood flow, which should not be the explanation for changes in albumin clearance, ${ }^{3}$ the increased RES activities on the third day after operation probably illustrate this same adaptative change in the Kupffer cells.

We thank Dr A Douglas at the Royal Victoria Infirmary, Newcastle upon Tyne, and Mr D Hancock of Sunderland Hospitals for access to patients under their care. Thanks are also due to the pharmacy staff at the Royal Victoria Infirmary for help in the preparation of materials.

\section{References}

${ }^{1}$ Filkins, J P, fournal of the Reticuloendothelial Society, 1971, 9, 480.

2 Mori, K, Matsumoto, K, and Gans, H, Annals of Surgery, 1973, 177, 159.

3 Normann, S J, Fournal of the Reticuloendothelial Society, 1973, 13, 47.

4 Mannik, M, and Arend, W P, fournal of Experimental Medicine, 1971, 134, No 3, part 2, 19s.

${ }^{5}$ Lee, L, Fournal of Experimental Medicine, 1963, 117, 365.

6 Wardle, E N, Archives of Surgery, 1974, 109, 741

7 Wardle, E N, Postgraduate Medical fournal, 1975, 51, 512.

${ }^{8}$ Wilikinson, S P, et al, Lancet, 1975, 1, 521.

${ }^{9}$ Nolan, J P, Gastroenterology, 1975, 69, 1346

10 Wardle, E N, Symposium on Endotoxin and the Liver, Würzburg, 1975.

11 Ilio, M, and Wagner, H N, fournal of Clinical Investigation, 1963, 42, 417.

12 Drivas, G, Uldall, P R, and Wardle, E N, British Medical fournal, 1975, 3, 743 .

13 Normann, S J, Laboratory Investigation, 1974, 31, 286.

14 Cooksley, W G E, Powell, L W, and Holliday, J W, British fournal of Haematology, 1973, 25, 147.

15 Wardle, E N, and Wright, N A, British Medical fournal, 1970, 4, 472.

16 Wardle, E N, Quarterly fournal of Medicine, 1975, 44, 389.

17 Farrer, W E, and Corwin, L M, Annals of the New York Academy of Sciences, 1966, 133, 668.

18 Alexander, J W, and Meakins, J L, fournal of Surgical Research, 1971, 11, 148.

19 Scovill, W A, and Saba, T M, Annals of Surgery, 1973, 178, 59.

20 Alexander, J W, Surgical Clinics of North America, 1972, 52, 1367.

\section{SHORT REPORTS}

\section{Tumour-induced autoimmune haemolytic anaemia}

Anaemia in patients with carcinoma is usually multifactorial. Autoimmune haemolytic anaemia in such patients is rare, however, and tests for autoantibodies almost always give negative results. ${ }^{1} \mathrm{We}$ report a case of adenocarcinoma of the caecum associated with haemolysis due to a "warm" type of IgG autoantibody within the rhesus blood group system. Haemolysis ceased after removal of the tumour, and lyophilised tumour material was shown to absorb completely the erythrocyte autoantibody.

\section{Case report}

A 71-year-old woman was admitted to hospital for investigation of anaemia. She complained only of increasing lethargy and dyspnoea for two months, having previously been in excellent health. There was no drug history, and she had not been exposed to any toxic agents. Examination showed severe pallor and a small mobile mass in the right iliac fossa. No lymphadenopathy or hepatosplenomegaly was found. Investigations showed autoimmune haemolysis (see table) with moderate numbers of spherocytes in the peripheral blood. Faeces were positive for occult blood, and barium enema confirmed the presence of a tumour in the caecum. Serological
Haematological and biochemical data

\begin{tabular}{|c|c|c|c|}
\hline Days after admission: & 0 & (before operation) & 28 \\
\hline $\begin{array}{l}\text { Haemoglobin }(\mathrm{g} / \mathrm{dl}) \\
\text { Reticulocytes }\left({ }^{\prime}(,)\right) \\
\text { Direct antiglobulin test } \\
\quad \text { result } \\
\text { Bilirubin (umol/1) } \\
\text { Haptoglobin }(\mathrm{g} / \mathrm{l})\end{array}$ & $\begin{array}{c}6 \cdot 8 \\
16 \\
\text { Strongly positive } \\
39 \\
0 \cdot 10\end{array}$ & $\begin{array}{c}13 \cdot 2 \\
27 \\
\text { Strongly positive } \\
56\end{array}$ & $\begin{array}{c}10 \cdot 9 \\
2 \\
\text { Negative } \\
20 \\
0.81\end{array}$ \\
\hline
\end{tabular}

Conversion: SI to traditional units-Bilirubin: $1 \mu \mathrm{mol} / 1 \approx 0.06 \mathrm{mg} / 100 \mathrm{ml}$.

investigations showed her to be group $\mathrm{B}, \mathrm{Rh}$-positive, most likely genotype $\mathrm{cDE} / \mathrm{cde}$. Serum and red-cell eluates contained two IgG autoantibodies, one a strong anti-c and the other a weaker, non-specific autoantibody. Immunoglobulin levels were normal.

Transfusion preoperatively with group $\mathrm{B}, \mathrm{CDe} / \mathrm{CDe}$ blood under cover of steroids was well tolerated. A right modified hemicolectomy was performed and a tumour $3.5 \times 3.5 \times 2.0 \mathrm{~cm}$ removed. There was no evidence of metastases. Histological examination showed a villous adenocarcinoma with abundant mucin secretion and areas of ossification in the stroma. Residual unfixed tumour was freeze-dried, and the lyophilised material completely neutralised the erythrocyte autoantibody. Dried erythrocyte stromata were not responsible, because antibodies to antigens known to be present on the red cells were not absorbed. Steroids given during the operation were stopped immediately afterwards, and reinvestigation 16 days later confirmed 